\title{
ROMANCE PROLETÁRIO EM RACHEL DE QUEIROZ OU VENDO O LADO DE FORA PELO LADO DE DENTRO
}

Luís Gonçales Bueno de Camargo ${ }^{*}$

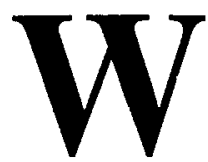

ilson Martins aponta como índice de confusão ideológica no início dos anos 30 a recepção dada pela crítica a dois romances lançados em 1931: O país do carnaval, de Jorge Amado, que foi lido como romance "católico", e $O$ esperado, de Plínio Salgado, que teria sido lido como "socialista".

Talvez fosse mais justo falar em "indefinição" do que em "confusão". Afinal de contas, Plínio Salgado ainda não havia se convertido ao integralismo nem Jorge Amado havia se aproximado da esquerda ${ }^{2}$. Nem tampouco havia se

* Universidade Federal do Paraná

1 MARTINS, Wilson. História da inteligência brasileira. v. 5, São Paulo: Cultrix/Edusp, p. 512.1978.

2 Cf. MIÉCIO TÁTI: Jorge Amado: Vida e obra, Belo Horizonte: Itatiaia, 1961, p. 40: "1932 seria para Jorge Amado data decisiva. Conheceu, por essa época, alguns dos escritores do chamado 'movimento de 30': José Américo de Almeida, Amando Fontes, Gilberto Freyre e Rachel de Queiroz, e por influência desta última chegaria à militância política, unido por fortes laços de compreensão e simpatia à corrente de esquerda." 
definido com clareza a polarização comunismo/fascismo que marcaria profundamente - e não somente no Brasil - a década de 30.

Derivada dessa indefinição ideológica vemos, nos domínios da literatura, uma confusão propriamente dita na caracterização, se não de um gênero, pelo menos de um rótulo - o "romance proletário". Essa confusão permaneceu, mas a expressão "romance proletário" acabou ganhando um sentido genérico razoavelmente estável.

O primeiro romance que, entre nós, se apresentou de alguma maneira ligado ao adjetivo proletário foi $O$ Gororoba, de Lauro Palhano, que trazia o subtítulo "Cenas da vida proletária".

A confusão se iniciou já com este livro, sobre o qual Agripino Grieco afirmou:

$O$ Gororoba inaugurou aqui, talvez sob o influxo da novíssima literatura russa, o romance proletário que ainda ignorávamos e que os leitores de Gladkov, o autor do Cimento, de Lebedinsky, Serafimovitch e outros, desejavam ver introduzido no Brasil. ${ }^{3}$

É espantoso que, tomando $O$ Gororoba em mãos, ao invés de uma visão socialista o que encontramos, na conclusão do livro, é o seguinte:

É inútil buscar um remédio para seus males, íntimos ou sociais, para o egoísmo que avassala o mundo, nas filosofias sem Deus, nas falhas do humano cérebro. Cristo deu a fórmula única, concisa e curta para curar essas lepras: - "Amai-vos uns aos outros"4.

Ou observações como estas:

A sociedade operária deve tender para a criaçāo de uma família operária, satisfeita no seu âmbito, ao nível do seu espírito, sem

3 GRIECO, Agripino. Evolução da prosa brasileira. Rio de Janeiro: Ariel, p. 304, 1933.

4 PALHANO, Lauro. O Gororoba. Rio de Janeiro, Terra do Sol, p. 362, 1931. 
confrontos humilhantes, sem lutas pelas posiçōes que, galgadas de chofre, podem causar vertigens.

Esta ânsia de grandezas é que lhe arrebata Zefa. Basília ambiciona um lar esplendoroso, que se não coadunaria com os hábitos dela, de sua mentalidade, de sua educaçāa 5 .

O que levaria Agripino Grieco a enxergar em $O$ Gororoba um "romance proletário"? Mais ou menos o mesmo que faz Jorge Amado reclamar do esquecimento desse romance que, a despeito de fazer "o operário fugir do seu caminho de revolta para cair na conformação que os padres pregam", "traz um vastíssimo documentário, um material imenso sobre a vida dos operários amazonenses e sobre os marítimos",

Ou seja, o simples fato de tematizar a vida operária garantiria ao romance o rótulo de "proletário".

Essa definição, que subjaz à observação de Agripino Grieco, embora bem pouco precisa do ponto de vista tanto da doutrina socialista quanto da própria teoria literária, seria, no final das contas, e depois de amplo debate, a que mais correntemente se usaria.

Esse debate em torno de uma definição de "arte proletária" no Brasil ganhou corpo um pouco depois da publicação de $O$ Gororoba e foi suscitado, em grande parte, por Jorge Amado. Em nota introdutória àquele que foi seu primeiro grande sucesso de público, Cacau, de 1933, ele se perguntava: "Será um romance proletário?",

Rapidamente vários críticos e escritores se puseram a responder à dúvida de Jorge Amado. Logo no mês seguinte ao aparecimento do romance, Alberto Passos Guimarães publicou no Boletim de Ariel artigo em que afirma que o "romance proletário não está definido senão doutrinariamente", mas, ao mesmo tempo, dá uma resposta direta à pergunta de Jorge Amado:

Ao meu ver, é. Embora impressionado mais pelo aspecto sentimental do problema, até a ligação afetiva do Sergipano, embora misturando algumas vezes as situações puramente morais com os sentimentos rebeldes da gente do campo, Cacau exala bem um ar de revolta para estar junto da literatura proletária.

5 PALHANO, op. cit., p. 189.

6 AMADO, Jorge. O Gororoba, Boletim de Ariel. Rio de Janeiro, ano III, n. 3, Rio de Janeiro, p. 71, dez. 1933.

7 Id. No País do Carnaval - Cacau - Suor, p. 101, São Paulo: Martins, s/d. 
Como se vê, o que o crítico aponta como traço básico do romance proletário é o ar de revolta, ou seja, que o livro se ponha em franca rebeldia contra uma sociedade que ele anteriormente mencionara como que desbotando a olhos vistos. É claro, no entanto, que esse aspecto de revolta apenas não é o bastante. A descrição da realidade do proletariado é também fundamental, sendo um dos aspectos de destaque do romance de Jorge Amado:

Todo o livro é uma reprodução muito exata da vida de bichos que, por esse Brasil afora, mais de três quartos da nossa população leva penosamente, com a dolorosa paciência de cegos .

Virando algumas páginas desse número do Boletim de Ariel, vê-se que quem contribui para a discussão sobre o romance proletário é o próprio Jorge Amado, tratando de Os Corumbas, de Amando Fontes. O romancista baiano nega a esse romance, por centrar-se numa família específica, a aplicação do rólulo. E define alguns traços:

A literatura proletária é uma literatura de luta e de revolta. E de movimento de massa. Sem herói nem heróis de primeiro plano. Sem enredo e sem senso de imoralidade. Fixando vidas miseráveis sem piedade mas com revolta ${ }^{9}$.

Jorge Amado ratifica a necessidade da presença da revolta e da descrição da vida dos miseráveis. Mas acrescenta a idéia de movimento de massa, que aboliria a unidade de enredo e o protagonista. Esses, aliás, seriam aspectos construtivos de seu romance seguinte, Suor.

No mês seguinte, Murilo Mendes se ocuparia da questão, tratando mais uma vez de responder a pergunta de Jorge Amado sobre Cacall. O poeta principia sua nota dizendo que antes de mais nada precisamos entender o que é que o autor entende como romance proletário, e acrescenta que não há propriamente como definir romance proletário: "sobretudo em países de capitalismo

8 GUIMARÃES, Alberto Passos. A propósito de um romance: Cacau. Bolletim de Ariel, Rio de Janeiro, ano 2, n. 11, p. 288, ago. 1933.

9 AMADO, Jorge. P.S. Boletim de Ariel, Rio de Janeiro, ano 2, n. 11, p. 292, ago. 1933. 
atrasado como o nosso, ainda não existe uma mentalidade proletária". No entanto, para ele,

o escritor que não encontrar motivos de inspiração na vida já em decomposição da sociedade burguesa, terá que observar a vida dos proletários e, se quiser ser um escritor revolucionário, terá que se integrar no espírito proletário, do contrário fará simples reportagem ${ }^{10}$.

Agora sob a chancela de "observação", novamente o elemento básico de uma literatura proletária seria sua proximidade com a vida operária - ainda que para Murilo Mendes essa ołservação não baste, não seja um fim em si, mas algo que conduza à integração nisso que ele chama de "espírito proletário". Tanto que o maior risco que corre o escritor é cair na reportagem, na pura observação da realidade.

Alguns meses depois, a discussão em torno da arte proletária ganharia uma nova contribuição, dada pelo crítico pernambucano Aderbal Jurema, num artigo em que desenvolvia com um pouco mais de vagar uma definição de literatura proletária, diferenciando-a de literatura revolucionária:

A literatura de esquerda está sendo chamada impropriamente de literatura proletária. Há uma grande distância a vencer entre a literatura revolucionária e a proletária. (...) Como a classe mais atingida pela exploração é a proletária, convencionou-se denominar todas as obras que narram o sofrimento dessa gente, de literatura proletária. (...) Nós nāo estamos sob um estado proletário e nem temos proletários romancistas. Essa literatura é revolucionária porque prega a revolução, é escrita por intelectuais de esquerda e visa despertar nas massas a sua consciência revolucionária. ${ }^{11}$

Mais preocupado com a questão doutrinária, Jurema detecta a existência de uma arte que narre o sofrimento da classe proletária. Posteriormente, num

10 MENDES, Murilo. Nota sobre Cacau. Boletim de Ariel, Rio de Janeiro, ano 2, n. 12, p. 317 , ago. 1934 .

11 JUREMA, Aderbal. Literaturas Reacionária e Revolucionária. Boletim de Aricl, Rio de Janeiro, ano 3, n. 8, p. 211, set. 1993. 
artigo sobre São Bernardo, ele cobraria de Graciliano Ramos a presença dessa atitude em seus romances. Assim, o que ele acaba fazendo é repensar a terminologia, chamando aquilo que em geral seria entendido como romance proletário de romance revolucionário.

Como seria de esperar, essa opinião está longe de ser consensual. Numa revista dirigida pelo próprio Jurema, manifestou-se diversamente dele Moacir de Albuquerque:

À primeira vista, parece correta a opinião do meu amigo [Aderbal Jurema, no seu artigo para o Boletim de Ariel]. Analisada, porém, ver-se-á que não resiste à crítica. Com efeito, admitindose, como ele admite, a existência aqui no Brasil, como em qualquer parte, da questão social, objetivada na luta de classes, nada mais lógico do que se chamar à arte que reflete essa realidade inegável, de "arte proletária".

Como já se disse, a questão que Jurema colocava não se referia à literatura propriamente dita, mas ao regime em que as obras apareciam, e Albuquerque o que faz é recolocar o rótulo mais ou menos onde estava antes da intervenção de Jurema.

Assim, apesar das discordâncias, o que sobra como elemento definidor do rótulo "romance proletário" é mais ou menos o que é sintetizado num artigo publicado em Momento:

Romance da gente bruta, de corpo sujo e alma limpa como de criança. História de miseráveis que gritam como condenados do inferno diante da natureza ora ressequida, ora estuante, mas sempre esterelizada pelo egoísmo de classe. ${ }^{13}$

A sobrevivência dessa noção vaga fica evidente quando lemos a clássica resenha de Lúcia Miguel Pereira sobre Vidas secas, em que ela opõe "proletário" ago. 1934.

12 AlbUQUeRQUE, Moacir de. Arte Proletária. Momento, Recife, ano 1, n. 4, p. 8, 1935.

13 BARBOSA, Orris. Romances do norte. Momento, João Pessoa, ano 2, n. 1, p. 3, out. 
a "universal"14, ou muito depois, quando Temístocles Linhares, passando solenemente por cima das preocupações de Jorge Amado, dirá que Os Corumbas seria nosso primeiro romance proletário ${ }^{15}$.

Em 1937, quando foi publicado Caminho de pedras, de Rachel de Queiroz, esse tema já não dominava tão fortemente a atenção do meio literário brasileiro. O romance de corte social, que predominara no início da década, já perdera o caráter de quase unanimidade que tivera.

Um crítico paranaense, Newton Sampaio, em resenha justamente sobre Caminho de pedras, esboça uma história dessa transformação do ambiente literário brasileiro. Faz um balanço de algumas das principais publicações desde que Rachel de Queiroz lançara João Miguel:

Durante esses quatro anos, terminou José Lins do Rego o nosso primeiro romance cíclico. E Lúcio Cardoso impôs-se como vigoroso analista de almas (...). E Cornélio Penna marcou entre nós, com Fronteira, um modo de ser fecundo e extremamente sério de atividade criadora. E Graciliano Ramos nos deu, com Angústia, um livro denso, compacto, diferente de tudo que anteriormente se realizara ${ }^{16}$.

Menciona ainda Erico Verissimo, que escrevera romances cheios de um carinho intenso pelos destinos dos seres e Jorge Amado, que "soube cobrir de poesia, soube eriçar de palpitações novas situações e almas baianas"17. Ou seja, Sampaio aponta uma transição de um realismo mais cru para uma tendência maior de interiorização e de efusão lírica no romance brasileiro. Por isso mesmo, para elc,

Caminho de pedras chegou depois... E chegou atrasado justamente porque esse capítulo de greves, de exaltações antibur-

14 PEREIRA, Lúcia Miguel, Vidas Secas. Boletim de Ariel, Rio de Janeiro, ano 7, n. 8 , p. 221, maio. 1938 .

15 LINHARES, Temístocles, História crítica do romance brasileiro, São Paulo/Belo Horizonte: Itatiaia/Edusp, 1987, v. 2, p. 269.

16 SAMPAIO, Newton. Caminho de Pedras, Uma Visão Literária dos Anos 30, Curitiba: Fundaçāo Cultural de Curitiba, p. 218, 1979.

17 lbid, p. 219. 
guesas, de ansiedades moscovitas, de "proletarizaçōes", com pixes nos muros, boletins sonorosos, não convence mais ${ }^{18}$.

Para o crítico, o livro só ganha interesse quando se liberta de presumíveis intençõs ideológicas:

As situações realmente interessam, quando revelam o v\$drama essencial de cada uma daquelas criaturas - esse drama que não depende de injustiças de regime ou de peripécias ideológicas -, para abrir sulcos profundos nas almas e fecundá-las, e engrandecê-las, com o sentido transfiguratório da dor ${ }^{19}$.

A resenha de Newton Sampaio é significativa por sintetizar a recepção que, de forma geral, o romance teve - para dizer o mínimo, uma recepção fria. Tão fria que despertou a solidariedade de um crítico importante como Almir de Andrade:

O acolhimento que fez a crítica ao último romance de Rachel de Queiroz contrasta de modo curioso com o acolhimento feito às suas obras anteriores. Ouvimos as acusaçōes as mais disparatadas e ridículas: até acusadores anônimos têm vindo à baila, aparecendo pela primeira vez nas colunas dos jornais para atirar em rosto da romancista cearense increpações nascidas não sei de que subterrâneas intenções de mediocridade e de despeito... Não se limitam eles à tentativa risível de criar escândalo em torno do romance: chegam a ferir a própria romancista, condenando-a à decadência e ao esgotamento da sua capacidade literária. ${ }^{20}$

Entretanto, na contramão de sua intenção de reabilitar o romance, Almir de Andrade acabou colaborando para construir uma determinada leitura dele

18 SAMPAIO, op. cit., p. 219.

19 Ibid., p. 220.

20 ANDRADE, Almir de. Caminho de Pedras. Boletim de Ariel, Rio de Janeiro, ano 6, n. 9 , p. 275 , jun. 1937. 
que, posteriormente, não evoluiu muito - além de, em certo sentido, corroborar uma leitura como a de Newton Sampaio. Após ressaltar que o livro tem muitas qualidades, aponta que também contém defeitos:

A parte proletária do romance, especialmente, fica muito aquém daquilo que a sua autora já deu sobejas demonstrações de poder realizar. Sente-se que Rachel de Queiroz teve necessidade de unir esse tema ao corpo do romance, e que essa necessidade se lhe impôs de modo imediato, sem esperar pela verdadeira inspiração. ${ }^{21}$

Nesse pequeno trecho, o crítico emite, na verdade, duas opiniões. A primeira, mais evidente, é a de que a romancista teria falhado numa parte do livro em que trataria de uma temática proletária. A outra, que não aparece explicitamente, mas da qual depende a primeira, é o fato de o livro ser divisível em duas partes que, em princípio, não se integram, já que uma está presente no romance à revelia da inspiração, ao passo que a outra merecerá todos os seus elogios a partir deste momento, o que é prova de que, para ele, é a parte legítima.

Essa outra parte seria dominada pela temática amorosa e pela superação de uma moral convencional, tendo como ponto de partida um triângulo amoroso. $O$ crítico centra toda sua leitura na idéia de que a autora teria trabalhado na oposição entre o exercício de liberdade interior e uma acomodação aos valores que seria de se esperar, em princípio, de uma mulher casada que se sentisse ligada a um outro homem.

A grande pergunta a se fazer aqui é: em que consiste essa tal parte proletária do romance? Rachel de Queiroz, que mais tarde diria não acreditar em literatura engajada, teria de fato intenção de fazer literatura proletária? ${ }^{22}$

O que Rachel de Queiroz faz na suposta parte proletária de Caminho de pedras não é nada disto. A descrição da vida miserável em Fortaleza é muito episódica. Pouco se mostra da vida cotidiana do operário e absolutamente nada de sua eventual purificação pelo sofrimento. $O$ operário que aparece no livro é aquele que participa de organizações políticas de esquerda. O personagem principal, Roberto, depois de dez anos de militância no Rio de Janeiro, volta a Fortaleza para organizar uma região, ou uma seção de uma organização de

21 ANDRADE, op. cit., p. 275.

22 Sobre a posição de Rachel de Queiroz frente à arte engajada, ver sua entrevista em Haroldo Bruno, Rachel de Queiroz, Rio de Janeiro/Brasília, Cátedra/INL, 1977, p. 120-121. 
esquerda, possivelmente o próprio Partido Comunista. Logo de início, há um descompasso entre as expectativas de Roberto e o que ele encontra na realidade: ao invés da conversa fraternal com os operários, uma troca viva de argumentos que já preparara ${ }^{23}$, solenidade e desconfiança:

- Pelo que eu entendi, o companheiro Roberto traz autorização para fundar uma Região aqui. O companheiro Roberto, apesar de não ser propriamente da nossa classe, é um rapaz sincero; mas os companheiros, depois que ele falou, ficaram calados, como desconfiando. Eu creio que assim não se faz nada.

O preto alto tomou a palavra:

- É porque nós já estamos fartos, camarada Rulino, de ir atrás dos doutores, e os doutores depois nos dão o fora. $\mathrm{O}$ opcrário tem que andar com os seus pés, é o que eu penso.

- O camarada Roberto trabalha conosco desde os tempos do Bloco Camponês!

- Ele pode ser sincero, mas chegando aqui é pra dominar! Vem organizar, vem chefiar, vem controlar... ${ }^{24}$

São várias as tentativas de aproximação com os operários, por parte tanto de Roberto como de outros intelectuais, entre os quais os operários incluem até mesmo Filipe, um guarda-livros de origem operária, que vive com a mãe num bairro operário, no areião, mas que conseguiu estudar e tem grande apego pelos livros.

Repetiam a toda hora os camaradas, afetavam uma simplicidade excessiva, que chocava os outros, os de tamanco, cheios de preconceitos e convenções. Pois a simplicidade, longe de ser um atributo dos humildes, é um artifício de requintados que a plebe desconhece. Depressa essa diferença cavou divergências. Os tamancos entraram a hostilizar os gravatas, a desmascará-los, a exigir que se proletarizassem. O preto Vinte-e-Um chefiava a esquerda, e os gravatas se fechavam num círculo aristocrático

23 QUEIROZ, Rachel de. Caminho de pedras, 8. ed. Rio de Janeiro: José Olympio, p. 7., 1985.

24 Ibid., p. 9. 
que chegava a incluir o próprio Filipe, expulso do meio dos obreiros por intelectual e burguês. Dos da rodinha, só Paulino, o ferroviário, tinha entrada entre os tamancos. Samuel também cortejava os operários e exagerava a sua proletarização. Deu até para andar de fundilhos rotos, de camisa de mescla. Pontificava e, por causa dessas concessões, era ouvido. ${ }^{25}$

Como não é difícil notar por este trecho, o que se vê no livro é o oposto daquele operário idealizado, limpo como criança. Ao contrário, é alguém desconfiado, hostilizando o tempo todo os companheiros não-proletários e exigindo deles um comportamento absolutamente artificial. Mas, acima disso, o que Caminho de pedras põe à mostra é o descompasso entre o intelectual e o operário, o problema da legitimação do intelectual dentro dos movimentos revolucionários de esquerda.

Em última análise, o romance acaba pondo em xeque mais do que a visão que a literatura autoproclamada "proletária" faz do próprio operário. O que ele aponta indiretamente é, se não uma possível artificialidade dessa arte proletária, feita por intelectuais que "podem até ser sinceros" mas se colocam como quem "vem organizar", pelo menos sua possível inocuidade junto àqueles para os quais ela se dirigiria.

O destino do livro só poderia ser o fracasso de crítica. Essa abordagem da militância de esquerda desagradaria até mesmo aqueles que, envolvidos nela, teriam em princípio motivos para aprovar a persistência nos temas proletários.

O grande problema é que a questão ideológica influiria na avaliação da própria estrutura do romance. Tanto Almir de Andrade quanto Newton Sampaio, como vimos, apontam uma fratura no romance. Mesmo já afastados do calor da hora, outros críticos acusam o romance desse defeito. Olívio Montenegro, por exemplo, simplesmente ignora a movimentação da militância no romance, fazendo toda sua discussão sobre o triângulo amoroso formado entre Noemi, Roberto e João Jaques ${ }^{26}$.

Quanto a Alfredo Bosi, é contundente em suas restrições ao romance:

A autora passa da crônica de um grupo sindical na morna Fortaleza da época à exploração sentimental de um caso de amor

25 QUEIROZ, op. cit., p.37.

26 MONTENEGRO, Olívio. Rachel de Queiroz. In: ORomance Brasileiro. Rio de Janeiro: José Olympio, 2. ed., 1953. 
de um par de pequena classe média afetado por ideais de esquerda ${ }^{27}$.

Essa crítica, escrita quando já se cristalizara a divisão teórica tão comum quando se trata do romance de 30 , entre literatura social e literatura intimista, que Bosi considera redutora, mas na qual recai constantemente, acabou fechando os olhos para o entrelaçamento que há no livro entre os dois planos, ou seja, o proletário e o amoroso.

Nesse sentido é preciso sublinhar o quanto a relação amorosa entre Roberto e Noemi se desenvolve em função da militância política. Noemi mantinha, como o marido João Jaques, uma relação de simpatia, mas também de distância com a militância de esquerda - João Jaques é um ex-militante totalmente desencantado com a militância, à qual adere apenas teoricamente. Seu passado de militante ativo em nenhum momento o romance esclarece, exceto que teria sido expulso da organização no Rio de Janeiro.

O grupo de operários e intelectuais que se reúne a partir da chegada de Roberto acaba atraindo Noemi e essa participação política efetiva acaba representando para ela uma verdadeira revelação:

(...) Vinha saindo do curso acompanhada por Roberto e Filipe. (...)

Era apenas uma alma livre, ouvindo a história de outras almas livres. Fugira do seu centro habitual de gravidade, perdera a noção do pão nosso de cada dia. Naquele momento, nada era moral nem imoral, nada proibido nem permitido; não havia hora, não havia espaço: só a cmbriaguez do momento de revelação, das possibilidades de libertação 28 .

Esse impacto que a militância promove na vida de Noemi acaba tornando incompatível sua relação com alguém que, desencantado, só consegue zombar e combater essa mesma militância. O afastamento de João Jaques é natural e, como se vê, é desencadeado pela questão ideológica. O mesmo se pode dizer da

27 BOSI, Alfredo. História concisa da literatura brasileira, Sāo Paulo: Cultrix, 3. ed., 1989, p. 447.

28 QUEIROZ, op. cit., p. 45. 
aproximação com Roberto, que acaba, em grande medida, guiando Noemi nesse mundo novo ao qual ela tem desejo de aderir. Assim, eles formam mais do que simplesmente um par de pequena classe média afetado por ideais de esquerda, mas um casal que se constitui através desses ideais de esquerda.

Reforçando esse aspecto há o contraponto do casamento de Noemi com o casamento de uma operária também militante, Angelita, que vive impasse semelhante. Numa greve recente, ela e o marido, Assis, estiveram juntos na luta. Assis foi preso e a família passou por sérias necessidades. Assim como João Jaques, Assis, no início do livro, está absolutamente afastado até mesmo da idéia de retomar sua atividade política. Convidado pela mulher a voltar à ativa ele simplesmente responde: "- Não sou mais besta."29

A exemplo de Noemi, Angelita se aproxima mais de seu amigo de infância, Filipe, companheiro na Organização. Ao final, porém, seu casamento não é ameaçado e sabemos, através do próprio Filipe que Angelita "conseguira animar um pouco o marido. Constava até que andava metido nuns peparativos de greve". 30

O que Caminho de pedras nos força a reconhecer é o erro na classificação apressada de Rachel de Queiroz como uma autora comprometida tão-somente com o romance social, como força o texto com que a editora José Olympio por muitos anos apresentou a autora:

Com vinte anos de idade apenas, uma quase desconhecida escritora provinciana projetava-se na vida literária do país agitando a bandeira do romance de fundo social, profundamente realista na sua mancira dramática exposição da luta secular de um povo contra a miséria e a seca. ${ }^{3}$

Pensando assim, Caminho de pedras nos faz rever com mais calma o conjunto dos romances da autora cearense publicados nos anos $30 \mathrm{em}$ pelo menos dois pontos: seu caráter realista c o problema que cles encerram no que diz respeito ao ponto de vista, ao lugar de onde falam os narradores desses romances.

Começando pelo primeiro desses pontos, é de se notar, em $O$ quinze, que toda a tragédia da seca aparece de permeio a inquietações pessoais de Conceição,

29 QUEIROZ, op. cil., p. 33.

30 Ibid., p. 98.

31 Nota da Editora, In: $O$ Quinze, Rio de Janeiro, José Olympio, 15. ed., 1972, p. 10. 
mesmo que estas ocupem espaço relativamente reduzido. Apesar das grandes diferenças que há entre os dois livros, pode ser útil comparar $O$ quinze a $A$ Bagaceira, de José Américo de Almeida, nesse aspecto. Concebidos antes mesmo de $O$ Gororoba, esses romances tratam antes do contraste entre as vidas miseráveis dos retirantes e de representantes da elite nordestina. Lembre-se que o enredo, em ambos os casos, fixa-se na trajetória destes e não daqueles, como seria de se esperar de um romance com preocupações eminentemente sociais ou "proletárias".

João Miguel, por sua vez, apresenta diferenças em relação a $O$ quinze. A própria situação do personagem central, João Miguel, já se coloca como propícia à introspecção: o romance acompanha seu período na cadeia de uma pequena cidade do interior cearense, por ter matado um homem. Por um lado, a descrição da cadeia, da situação da Justiça, da impunidade dos matadores profissionais protegidos pelos políticos tem forte apelo realista - "proletário" no sentido que vimos, por fixar a tragédia de um miserável à mercê de forças sociais em tudo distantes e acima dele. Mas, por outro lado, a constante inquirição que João Miguel faz acerca tanto de sua situação de preso, como, principalmente, sobre as razões e consequiências de seu crime, nos dão páginas de intenso "intimismo". Exemplo bem acabado desse traço forte dentro do romance são os momentos em que o personagem passa por uma verdadeira "crise de identidade". Não consegue se sentir diferente do que era - não consegue se enxergar como um criminoso - e, ao mesmo tempo, não consegue entender por que, não sendo criminoso, não se sente arrependido pelo crime que cometeu.

Assim, o romance As três Marias, que abandona de vez a temática "proletária" para focalizar a vida de moças de classe média em Fortaleza, apenas acentua um traço que marca a obra de Rachel de Queiroz como um todo. Ele é continuador de Caminho de pedras, não por causa da acentuação do plano psicológico, como frisa Alfredo Bosi, já que a força desse plano vem de antes, mas por explorar um mesmo tema: a superação, por parte da mulher, de papéis estabelecidos por uma moral convencional. Note-se de passagem, que esta é uma contribuição importante, na década de 30, de escritoras como Rachel de Queiroz e Lúcia Miguel Pereira - esta especialmente em Amanhecer, mas de certa forma já em Em surdina - que fogem do automatismo quase irritante, encontrável em muitos romances da época, que faz de toda mulher que perde a virgindade uma prostituta.

A segunda questão a ser reconsiderada, como se disse, é a do ponto de vista. Alfredo Bosi coloca de maneira bastante negativa esse problema, dizendo que Caminho de pedras 
(...) é um romance populista, isto é, um romance que situa as personagens pobres de fora, como quem observa um espetáculo curioso que, eventualmente, pode comover ${ }^{32}$.

Aceitando o que se negou até aqui, ou seja, que as personagens pobres estejam no primeiro plano, é inegável que o romance traga essa visão de fora. Mas, em primeiro lugar, ela não é exclusiva deste romance. Isso ocorre desde $O$ quinze, onde o drama da seca é apresentado a partir da ótica de Conceição, uma não-retirante, uma não-miserável - vale aqui, portanto, o que se disse há pouco sobre o romance de estréia de Rachel de Queiroz. Além disso, confrontada com outras do mesmo período, a obra de Rachel de Queiroz demonstra, nesse apecto, mais clarividência do que pode aparentar.

Para além do apelo sentimental que Alfredo Bosi aponta - de resto em grande parte negado pelo estilo, dos mais sóbrios ${ }^{33}$ - a escritora cearense trouxe a questão social para seus romances como pôde. Afinal, até que ponto é possível a um intelectual oriundo das camadas médias ou até mesmo altas da sociedade tratar da pobreza "de dentro"? Jorge Amado, que tanto se esforçou nesse sentido, não obteve resultados nem literários e nem eventualmente "políticos" melhores que os de Rachel de Queiroz. Ao contrário, ele se assemelha àqueles militantes que se tornam artificiais na tentativa de se "proletarizar", ou seja, identifica-se em parte com um dos pólos do desencontro tematizado em Caminho de pedras entre intelectuais e operários. Nesse sentido, o incoerente seria Rachel de Queiroz tentar uma visada "de dentro" de cujo sucesso ela própria demonstra duvidar.

Porém se insistirmos na leitura segundo a qual o foco de atenção do romance não está sobre as personagens pobres, mas sim sobre a militância política - ou sobre a relação entre proletários e não-proletários envolvidos na militância -, Caminho de pedras poder ser visto, sim, como um romance que traz uma visão "de dentro". Mas, é bom insistir, esse "dentro" referindo-se àquilo que o romance de fato tematizou, ou seja, não a vida dos proletários, mas a vida em uma organização política de esquerda, sempre tomada a partir de personagens não-operários, os "de gravata".

32 BOSI, op. cit., p. 447.

33 A esse respeito, por exemplo, Olívio Montenegro é categórico: “Para muitos leitores não duvido que o romance de Rachel de Queiroz não acabe parecendo um romance seco, de pouca ternura e pouca poesia. (...) Efetivamente não há sonoridade poética na prosa de Rachel de Queiroz." Ver MONTENEGRO, op. cit., p. 280. 
Pensando assim, é interessante notar como há semelhanças entre Caminho de pedras e um depoimento publicado mais de quarenta anos depois, o de Fernando Gabeira em $O$ que é isso, companheiro?

"Por que os operários nos olhavam com tanta desconfiança e frieza?"34, pergunta-se Gabeira como se perguntava o personagem Roberto em seu primeiro encontro com os membros do bloco operário.

A mesma cobrança de proletarização sentida pelos intelectuais, seguida do efetivo esforço de proletarização por parte de alguns, que já se comentou aqui quanto ao romance de Rachel de Queiroz, aparece no livro de Gabeira:

Alguns estudantes se consideravam operários e me viam como um intelectual que se tinha passado para o seu lado, mas ainda não se curara, completamente, de suas deformações. (...) Várias vezes falei contra o processo de proletarização. ${ }^{35}$

Não é no detalhe, mas sim na concepção básica do romance, na confluência da tematização da militância com a tematização do amor que une aquilo que, como vimos, vários entenderam como partes estanques da obra, que a homologia entre os livros se faz mais perceptível.

Noemi, quando decide abandonar João Jaques para viver com Roberto, enfrenta problemas enormes, de parte a parte. A incompreensão do "mundo burguês" era de se esperar, e ninguém se surpreende quando Noemi é demitida do estúdio fotográfico onde trabalhava:

Pois ele [o patrão] sentia muito... Dona Noemi tinha sido uma boa empregada, não tinha queixa a fazer. Mas a fotografia era freqüentada por famílias, a freguesia principal era de primeiras comunhões, noivas, grupos de pai, mãe, filharada... Dona Noemi compreendia... Já tinham reclamado. ${ }^{36}$

34 GABEIRA, Fernando. O que é isso companheiro?. 23. ed. Rio de Janeiro: Codecri, p. 54,1981 .

35 lid, p. 143.

36 QUEIROZ, op. cit., p. 96. 
O que poderia surpreender aqueles que associam luta operária e superação dos preconceitos morais é a reação dos companheiros da organização:

Muito se comentou na rodinha da praça, no curso em casa de Angelita, em todos os pontos de reunião, os amores de Noemi e Roberto, a inesperada partida de João Jaques.

Em geral condenavam Noemi. Ainda era muito vivo, em todos, o terror do adultério. Queriam ser independentes, tinham idéias, mas no fundo do coração tinham horror da coisa ruim, do nome feio.

E depois, era patente que Roberto e Noemi eram amantes há muito tempo, mesmo nas barbas do marido. Quem sabe até se ele não ignorava nada... "Cachorrices de pequeno-burguês"... Samuel bem que tinha dito: "As mulheres daqui ainda não estāo maduras para a luta... Confundem questão social com questão sexual..."37

É gritante a semelhança entre essa experiência vivida na ficção de Rachel de Queiroz e a experiência relatada por Gabeira:

Zé Roberto foi morto em janeiro de 70, depois de cercado pela polícia. Levou um tiro na cabeça. E eu me casei com sua companheira Vera, assim que saímos da cadeia e debaixo da crítica de alguns, que achavam não ter sido cumprido o tempo regulamentar do luto. Fomos muito felizes, dentro dos limites ${ }^{38}$.

Se Gabeira falou de "dentro" de uma experiência de militância, por que Rachel de Queiroz, que aponta as mesmíssimas questōes, teria falado de "fora"? Certamente, o que incomoda a Bosi é a evolução ideológica da autora, que ele faz questão de ressaltar:

37 QUEIROZ, op cit., p. 92. Compara-se este juízo do personagem Samuel com este outro, de Murilo Mendes, sobre Parque Industrial, de Patrícia Galvão, no texto do Bolctim de Ariel já mencionado: "Parece que para a autora o fim da revolução é resolver a questão sexual."

38 lbid., p. 54. 
Já a curva ideológica da escritora poderá parecer estranha, paradoxal mesmo: do socialismo libertário de Caminho de pedras às crônicas recentes de espírito conservador. ${ }^{39}$

Ora, o ponto onde essa "curva" foi dar não pode servir de filtro para a leitura de um romance escrito de seu ponto oposto, o de partida.

Fazendo o esforço de ler o livro de Rachel de Queiroz contra o pano de fundo do momento em que foi escrito, o que temos nas mãos é um romance admirável. $\mathrm{E}$ isso tanto formalmente, enquanto romance mesmo, quanto ideologicamente. Fugindo dos vícios de uma proletarização postiça para a arte, Caminho de pedras é emblemático de um momento rico, ainda pouco discutido de nossa literatura, em que o romance social dava mostras de esgotamento.

Rachel de Queiroz fez um livro de grande lucidez. Tirou matéria para sua literatura da questão proletária, mas olhando-a da posição que lhe era legítima: "de fora" do universo propriamente proletário, mas "de dentro" da experiência do intelectual, que fica sempre no limite entre "dentro" e "fora" desse universo. Exceto talvez por um esforço desmesurado de desenraizamento de que poucos são capazes e cuja validade é discutível.

\section{RESUMO}

Embora muito discutida, a idéia de "romance proletário" nos anos 30 ficou indefinida, exceto por um traço fundamental: a fixação da vida dos miseráveis. Por tematizar a militância proletária, Caminho de pedras foi visto como "romance proletário". Discutido tendo em vista esse parâmetro, tem sido considerado um romance falho pela crítica. Este trabalho propõe uma outra leitura, segundo a qual o romance não é nem pretende ser um romance da vida proletária, mas um romance da militância de esquerda capaz de enxergar os limites de si própria. 


\section{ABSTRACT}

Many authors of the thirties tried to determine "labourer's novel" which remained undefined, except for the fact that such a kind of literature had to describe poor people lives. Critics have been analysing Rachel de Queirozs Caminho de pedras as a bad "labourer's novel" since it was first published in 1937. However, if we take into account that this book not even intends to be about labourers lives, but about people involved in political movements as well as the shock between intelectuals and labourers inside the Communist Party, Caminho de Pedras can be considered very successful in showing the boundaries of intelectual action inside labourers political movements.

\section{REFERÊNCIAS BIBLIOGRÁFICAS}

ALBUQUERQUE, Moacir de. Arte Proletária. Momento. Recife, ano 1, n. 4, agosto de 1934.

AMADO, Jorge. O Gororoba. Boletim de Ariel, Rio de Janeiro, ano 3, n. 3, Dez. 1933. .P. S. Boletim de Ariel, Rio de Janeiro, ano 2, n. 11, ago. 1933. . No país do carnaval - Cacau - Suor. São Paulo. Martins, s/d.

ANDRADE, Almir de. Caminho de Pedras. Boletim de Ariel. Rio de Janeiro, ano 6, n. 9, jun. 1937.

BARBOSA, Orris. Romances do Norte. Momento, João Pessoa, ano 2, n. 1, p. 3, out. 1935.

BOSI, Alfredo. História concisa da literatura brasileira. São Paulo: Cultrix, 3. ed., 1989. BRUNO, Haroldo. Rachel de Queiroz, Rio de Janciro/Brasília: Cátedra/INL, 1977, JUREMA, Aderbal. Literaturas Reacionária e Revolucionária. Boletin de Ariel, Rio de Janeiro, ano 3, n. 8, maio de 1934, p. 211.

GABEIRA, Fernando. O que é isso companheiro?. Rio de Janeiro: Codecri, 23. ed., 1981 GRIECO, Agripino. Evolução da prosa brasileira, Rio de Janeiro, Ariel, 1933.

GUIMARÃES, Alberto Passos. A propósito de um romance: "Cacau". Boletim de Ariel Rio de janeiro, ano 2, n. 11, ago. 1933.

LINHARES, Temístocles. História crítica do romance brasileiro. São Paulo/Belo Horizonte, Edusp:Itatiaia, 1987

MARTINS, Wilson. História da inteligência brasileira. São Paulo: v. 5, Cultrix/Edusp, 1978.

MENDES, Murilo. Nota sobre "Cacau". Boletim de Ariel, Rio de Janeiro, ano 2, n. 12 , set. 1933.

MONTENEGRO, Olívio. O romance brasileiro. Rio de Janeiro: José Olympio, 2. ed.,1953.

PALHANO, Lauro. O Gororoba. Rio de Janeiro: Terra do Sol, 1931. 
CAMARGO, L. G. B. de. Romance Proletário em Raquel de Queiroz

PEREIRA, Lúcia Miguel. Vidas Secas. Boletim de Ariel. Rio de Janeiro, Ano 7. n. 8, maio 1938.

QUEIROZ, Rachel de. Caminho de pedras, Rio de Janeiro: José Olympio, 8. ed., 1985. .O quinze, Rio de Janeiro: José Olympio, 15. ed., 1972.

SAMPAIO, Newton. Uma visão literária dos anos 30. Curitiba: Fundação Cultural de Curitiba, 1979.

TÁTI, Miécio. Jorge Amado: Vida e obra. Belo Horizonte: Itatiaia, 1961. 